\title{
Infusion of glucose and fructose in healthy horses
}

\author{
Infusão de glicose e frutose em equinos sadios
}

\author{
Monica Miranda Hunka ${ }^{1}$, Luzilene Araujo de Souza ${ }^{1}$, Fernando Leandro dos Santos ${ }^{1}$, Waleska Ferreira Dantas ${ }^{2}$, \\ Helena Emília Cavalcanti da Costa Cordeiro Mansoํㅜ, José Mário Girão de Abreu³ , José Dantas Ribeiro Filho ${ }^{4}$, \\ Hélio Cordeiro Manso Filho ${ }^{1^{*}}$ \\ ${ }^{1}$ Universidade Federal Rural de Pernambuco (UFRPE), Recife, PE, Brazil \\ 2 União de Ensino Superior de Viçosa (UNIVIÇOSA), Viçosa, MG, Brazil \\ ${ }^{3}$ Universidade Estadual do Ceará (UECE), Fortaleza, CE, Brazil \\ ${ }^{4}$ Universidade Federal de Viçosa (UFV), Viçosa, MG, Brazil
}

\begin{abstract}
The aim of this study was to evaluate the metabolic response of five healthy non-pregnant Arabian mares to intravenous glucose or fructose infusions with commercial energy-boosting electrolyte supplements. The animals were kept on a dry lot and had free access to Tifton 85 hay, mineral salt and water. A full factorial experiment was carried out with five horses and five treatments, as follows: corn (control), fructose $25 \mathrm{~g}$ (Fru-25); fructose $50 \mathrm{~g}$ (Fru-50); glucose 25g (Glu-25); and glucose $50 \mathrm{~g}$ (Glu-50). The fructose and glucose solutions were infused into the jugular vein within 10 minutes, regardless of their volume, in doses ranging from $0.13 \mathrm{~g} / \mathrm{Kg}$ (Fru-50 and Glu-50) to $0.07 \mathrm{~g} / \mathrm{Kg}$ (Fru-25 and Glu-25). Blood samples were drawn from the jugular vein at seven moments: 0 or pre-test (fasting), and $30,60,90,120,180$, and 240 minutes after beginning the intravenous supplementation or food ingestion

plasma protein (TPP) and insulin levels. The results were subjected to ANOVA and to Tukey's test, with a p-value of 0.05 , using SigmaPlot 13.0 software. The results indicated that glucose, insulin, ALT and AST levels differed significantly between treatments and blood sampling times. Only glucose showed high interaction between treatments and periods ( $\mathrm{p}<0.001$ ). Glu-50 produced higher glucose concentrations at $+30,+60$ and $+90 \mathrm{~min}$. The insulin concentration was higher at +30 and $+60 \mathrm{~min}$ in Glu-25, Fru-50 and Fru-25 ( $\mathrm{p}<0.05)$. On the other hand, there was no difference in total phosphorus and protein levels between treatments between the periods ( $p>0.05$ ). In conclusion, this research demonstrated that glucose or fructose infused into the bloodstream of healthy mares produced different glycemic and insulin curves when equivalent doses of commercial energyboosting supplements were used.
\end{abstract} (corn). The following blood biomarkers were analyzed: glucose, insulin, aspartate aminotransferase (AST), alanine aminotransferase (ALT), phosphorus, total
Keywords: Carbohydrates. Glycemic curve. Insulin. Liver transaminase. 


\section{Resumo}

Objetivou-se com este estudo avaliar a resposta metabólica em cavalos após a infusão intravenosa de glicose e frutose, na forma de suplemento energético e eletrolítico comercial. Utilizou-se cinco éguas da raça Árabe, não prenhes e em manutenção, suplementadas com feno de Tifton, com água e sal mineralizado ad libitum. Utilizou-se o método fatorial, com cinco animais e cinco tratamentos, a saber: milho em grão (controle), frutose $25 \mathrm{~g}$ (Fru-25), frutose 50 $g$ (Fru-50), glicose $25 \mathrm{~g}$ (Glu-25) e glicose $50 \mathrm{~g}$ (Glu-50). As soluções de glicose e frutose foram administradas por via intravenosa, no período de 10 minutos, independentemente do volume. As doses utilizadas foram 0,13 g/Kg (Fru50 e Glu-50) e 0,07 g/Kg (Fru-25 e Glu-25). Amostras de sangue foram colhidas em sete momentos: 0 ou pré-teste (jejum) e 30, 60, 90, 120, 180 e 240 minutos após o início da infusão intravenosa ou ingestão de grãos (controle). Analisou-se glicose, insulina, aspartato aminotransferase (AST), alanina aminotransferase (ALT), fósforo e proteínas plasmáticas totais. Os resultados foram submetidos aos testes ANOVA e de Tukey, com significância estabelecida em 5\%; utilizou-se o aplicativo Sigmaplot 13.0. Os resultados mostraram que a glicose, insulina, AST e ALT apresentaram diferenças significativas entre os tratamentos e períodos da coleta do sangue. Somente a glicose mostrou elevada interação entre os tratamentos e os períodos $(p<0,001)$. o Glu-50 produziu maiores concentrações de glicose em $+30,+60$ e +90 min. A concentração de insulina foi mais elevada em +30 e +60 min em Glu-25, Fru-50 e Fru-25 ( $p$ $<0,05)$ Por outro lado, não houve diferença nos níveis de fósforo e proteínas totais entre os tratamentos nem entre os períodos $(p>0,05)$. Concluiu-se que a infusão sanguínea de glicose e frutose produziu diferentes curvas glicêmicas e insulinêmicas em cavalos sadios quando se utilizou doses equivalentes de produtos comerciais energéticos.

Palavras-chave: Carboidratos. Curva glicêmica. Insulina. Transaminase hepática.

\section{Introduction}

Intravenous treatments for horses and other equines to maintain or replace calories with different types of carbohydrates is a common practice, albeit poorly understood, particularly because it is forbidden in some equestrian sports. The International Federation for Equestrian Sports (FEI), for example, has rules against calorie infusion during equestrian competitions for many equine athletes. However, in regional equestrian sports in Brazil and other countries around the world, this kind of supplementation is a common practice that does not appear to be governed by official regulations. Veterinarians, horse trainers and owners have access to different products containing carbohydrates (glucose, dextrose and fructose), which are regularly sold directly without a prescription and can be used on horse farms and veterinary hospitals for equines in various conditions, such as newborn foals and horses after undergoing abdominal surgery.

Energy boosting and hydration treatment by infusion with fructose and/or glucose solutions in humans is a common practice (Elliott et al., 2002). Intravenous infusion with glucose and/or fructose has been shown to produce a similar amount of glycogen in the liver and skeletal muscle of healthy humans (Nilsson and Hultman, 1974). However, only fructose is rapidly processed in the liver, whose cells capture it continuously, but this is not the case with glucose infusions (Geidl-Flueck and Geber, 2017). Also, it should be noted that only chronically high levels of fructose ingestion are associated with obesity and metabolic syndrome in humans (Elliott et al., 2002), and that rapid infusions of large doses of fructose may increase blood lactate levels and cause changes in blood $\mathrm{pH}$ (Kaye et al., 1958; Pribylová et al., 1973; Steinmann et al., 2016). These characteristics of the fructose metabolism, especially rapid metabolization in the liver, justify the use of fructose in equine medicine, not only to restore caloric status without significantly increasing insulin secretion but also to improve energy stores in horses suffering from different diseases, such as laminitis and metabolic syndrome.

Few studies have focused on increasing the body of knowledge about the possible effects of fructose on horses. It has been demonstrated that oral fructose supplementation is well absorbed and converted to glucose, and no difference has been observed between blood glucose and insulin in horses supplemented with oral glucose or fructose 
(Bullimore et al., 2000). In contrast, Vervuert et al. (2004) showed that oral supplementation of horses with glucose produced a higher glycemic response than fructose supplementation at rest and during exercise. In addition, it was recently reported that fructose supplementation did not produce major endothelial dysfunction or increase the risk of vascular complications in equines (Borer et al., 2012). This is important to prevent laminitis in sick horses or animals with metabolic syndrome and other disorders. The aim of this study was to evaluate the metabolic response of horses to glucose or fructose after an intravenous infusion of energy-boosting electrolyte supplements. Our initial assumption was that these two carbohydrates would lead to similar increases in glucose and insulin levels in healthy horses.

\section{Material and methods}

\section{Animals}

This study involved five non-pregnant Arabian mares (weight: $\sim 380 \mathrm{Kg}$, age: $\sim 14$ years; body condition score: 4.5 ) that were kept on a dry lot and had free access to Tifton 85 hay, mineral salt for horses and water. The mares were not fed pellets or concentrate during the 30 days prior to this study. Mellor's Five Domains Model was applied to these animals to ensure their welfare and maintain their health and vigor (Mellor, 2017). The project was approved by the Ethics Committee on Animal Use of the Federal Rural University of Pernambuco (CEUAUFRPE), under Protocol No. 077/2016.

\section{Fructose and glucose supplementation}

A full factorial design was carried out with five horses and five treatments, as follows: corn (control), fructose $25 \mathrm{~g}$ (Fru-25), fructose $50 \mathrm{~g}$ (Fru50 ), glucose $25 \mathrm{~g}$ (Glu-25), and glucose $50 \mathrm{~g}$ (Glu50 ). Each treatment was followed by an interval of three days. Fructose (Polijet ${ }^{\circledR}$ HD, Vetoquinol Saúde Animal Ltda) and dextrose (d-glucose) (Hertavita, Hertape Calier Saúde Animal) were obtained from commercial products that are normally used on horses in Brazil. These products have very similar formulations which include electrolytes, complex B vitamins, and water. Using a catheter, all the fructose and glucose solutions were infused into the jugular vein within 10 minutes, regardless of their volume, in doses varying from $0.13 \mathrm{~g} / \mathrm{Kg}$ (Fru-50 and Glu50 ) to $0.07 \mathrm{~g} / \mathrm{Kg}$ (Fru-25 and Glu-25). The control treatment (1.0 Kg of corn) was fed to the horses in their individual stalls, where they had free access to fresh water.

\section{Blood sampling and analysis}

Blood samples were drawn from the jugular vein into heparin vacuum blood collection tubes after overnight fasting. This sampling was performed at seven moments: 0 or pre-test (fasting), and 30, $60,90,120,180$, and 240 minutes after beginning the intravenous supplementation or food ingestion (corn). The biochemical parameters (glucose, insulin, aspartate aminotransferase (AST), alanine aminotransferase (ALT) and phosphorus levels) were analyzed using a semiautomatic biochemistry analyzer (D-500, Doles) and commercial kits for each biomarker. Insulin levels were analyzed by the ELISA test method, using a commercial kit (Human Insulin Elisa BioAssay Systems, Ca, USA). Total plasma protein (TPP) was measured using a manual refractometer. All the samples were analyzed in duplicate.

\section{Statistical analysis}

The analytical results were subjected to two-way ANOVA (treatment and time/period) and to Tukey's test, with a p-value of 0.05 . All the analyses were performed using SigmaPlot 13.0 software (Systat Software, Inc) and the results are expressed as mean \pm average standard error.

\section{Results}

The results of two-way ANOVA (Table 1) indicated that glucose, insulin, ALT and AST levels varied significantly between treatments and blood collection times. However, only glucose levels showed a significantly high correlation between treatment and sampling times $(p<0.001)$. In contrast, 
TPP and phosphorus levels showed no variations between treatments and over time ( $p>0.05)$.

An analysis of the concentration of various biomarkers in the different treatments indicated that the Glu-50 treatment produced the highest glucose and insulin levels ( $\mathrm{p}<0.05)$, while the corn treatment (control) showed the lowest glucose level $(\mathrm{p}<0.05)$ and the Glu-25 treatment the lowest insulin level $(\mathrm{p}<0.05)$ (Table 2). The Fru-50 and Glu-50 treatments produced similar plasma glucose levels ( $p>0.05)$, but different results for insulin levels in +30 min $(p<0.05)$. Moreover, the Glu-50g, Fru-25 and Fru-50 treatments were found to lower the ALT and AST levels $(p<0.05)$.

An evaluation of plasma glucose levels throughout the experimental period indicated that
Glu-50 produced higher levels at $+30,+60$ and +90 min, and Corn produced lower ones at those times $(\mathrm{p}<0.05)$ (Table 3). In addition, insulin levels were higher at +30 and +60 min in all the treatments, except in the Glu-25 treatment $(\mathrm{p}<0.05)$. After 120 min, all the treatments produced similar glucose and insulin had levels ( $p>0.05)$ (Table 4).

Finally, it is important to note that no animals exhibited any clinical problems either during or after the experimental phase. After the last blood sampling, the animals were fed a small amount of concentrate $(2.0 \mathrm{~kg})$ and Tifton 85 hay before returning to their pasture. Also, throughout the blood collection period, a member of our research team interacted positively with all the mares, providing behavioral and mental comfort to avoid any suffering.

Table 1 - Two-way ANOVA results for different biomarker levels, as a function of treatment and time, in horses treated with different fructose and glucose doses infused via jugular vein, or corn (control)

\begin{tabular}{lccc}
\hline Biomarkers & \multicolumn{3}{c}{ Results of two-way ANOVA } \\
\cline { 2 - 4 } & Treatment (p-value) & Time (p-value) & Interaction (p-value) \\
\hline Glucose & $<0.001$ & $<0.001$ & $<0.001$ \\
Insulin & $<0.004$ & $<0.001$ & $>0.05$ \\
Alanine aminotransferase & $<0.001$ & $>0.05$ & $>0.05$ \\
Aspartate aminotransferase & $<0.001$ & $>0.05$ & $>0.05$ \\
Phosphorus & $>0.05$ & $>0.05$ & $>0.05$ \\
Plasma protein & $>0.05$ & $>0.05$ & $>0.05$ \\
\hline
\end{tabular}

Table 2 - Biomarker levels in horses after infusion with different oral doses of fructose, glucose, or feeding with corn grain

\begin{tabular}{lccccc}
\hline Biomarkers & \multicolumn{5}{c}{ Treatments } \\
\cline { 2 - 6 } & Corn & Glu-50 & Glu-25 & Fru-50 & Fru-25 \\
\hline Glucose $(\mathrm{mg} / \mathrm{dL})$ & $89.76 \pm 1.46^{\mathrm{c}}$ & $112.52 \pm 1.46^{\mathrm{a}}$ & $102.38 \pm 1.46^{\mathrm{ab}}$ & $100.95 \pm 1.46^{\mathrm{ab}}$ & $97.14 \pm 1.46^{\mathrm{b}}$ \\
Insulin $(\mu \mathrm{UI} / \mathrm{mL})$ & $4.83 \pm 1.02^{\mathrm{abc}}$ & $8.42 \pm 1.02^{\mathrm{a}}$ & $3.08 \pm 1.02^{\mathrm{c}}$ & $7.28 \pm 1.02^{\mathrm{ab}}$ & $6.07 \pm 1.02^{\mathrm{abc}}$ \\
AST $(\mathrm{UI} / \mathrm{L})$ & $259.45 \pm 6.83^{\mathrm{a}}$ & $165.08 \pm 6.83^{\mathrm{b}}$ & $256.50 \pm 6.83^{\mathrm{a}}$ & $169.69 \pm 6.83^{\mathrm{b}}$ & $187.47 \pm 6.83^{\mathrm{b}}$ \\
ALT $(\mathrm{U} / \mathrm{L})$ & $5.49 \pm 0.29^{\mathrm{abc}}$ & $5.04 \pm 0.29^{\mathrm{c}}$ & $6.34 \pm 0.29^{\mathrm{ab}}$ & $3.66 \pm 0.29^{\mathrm{d}}$ & $5.94 \pm 0.29 \mathrm{~A}^{\mathrm{ab}}$ \\
Phosphorus $(\mathrm{mg} / \mathrm{dL})$ & $5.33 \pm 0,17$ & $5.19 \pm 1.6$ & $5.48 \pm 0.16$ & $5.15 \pm 0.16$ & $5.00 \pm 0.16$ \\
Plasma protein $(\mathrm{mg} / \mathrm{dL})$ & $7.18 \pm 0.07$ & $7.18 \pm 0.07$ & $6.95 \pm 0.07$ & $7.16 \pm 0.07$ & $7.11 \pm 0.07$ \\
\hline
\end{tabular}

Note: Different letters on the same line indicate $p<0.05$ by Tukey's test; Fru-25 = fructose $25 \mathrm{~g}$; Fru-50 = fructose $50 \mathrm{~g} ;$ Glu-25 = glucose $25 \mathrm{~g}$; Glu-50 = glucose $50 \mathrm{~g}$; AST: Aspartate aminotransferase; ALT: Alanine aminotransferase. 
Table 3 - Glucose levels and variations thereof between treatments at different blood sampling times

\begin{tabular}{lccccc}
\hline Sampling time & \multicolumn{5}{c}{ Glucose (mg/dL) } \\
\cline { 2 - 6 } & Corn & Glu-50 & Glu-25 & Fru-50 & Fru-25 \\
\hline Pretest & $79.00 \pm 3.86$ & $89.67 \pm 3.86$ & $89.67 \pm 3.86$ & $85.33 \pm 3.86$ & $90.00 \pm 3.86$ \\
$+30 \mathrm{~min}$ & $83.33 \pm 3.86^{\mathrm{d}}$ & $163.00 \pm 3.86^{\mathrm{a}}$ & $127.33 \pm 3.86^{\mathrm{b}}$ & $113.00 \pm 3.86^{\mathrm{bc}}$ & $105.00 \pm 3.86^{\mathrm{cd}}$ \\
$+60 \mathrm{~min}$ & $90.67 \pm 3.86^{\mathrm{d}}$ & $138.33 \pm 3.86^{\mathrm{a}}$ & $111.67 \pm 3.86^{\mathrm{bc}}$ & $114.33 \pm 3.86^{\mathrm{b}}$ & $100.00 \pm 3.86^{\mathrm{bcd}}$ \\
$+90 \mathrm{~min}$ & $95.00 \pm 3.86^{\mathrm{b}}$ & $118.33 \pm 3.86^{\mathrm{a}}$ & $102.67 \pm 3.86^{\mathrm{b}}$ & $104.33 \pm 3.86^{\mathrm{ab}}$ & $97.67 \pm 3.86^{\mathrm{b}}$ \\
$+120 \mathrm{~min}$ & $94.00 \pm 3.86$ & $103.67 \pm 3.86$ & $93.67 \pm 3.86$ & $96.00 \pm 3.86$ & $95.00 \pm 3.86$ \\
$+180 \mathrm{~min}$ & $96.67 \pm 3.86$ & $88.00 \pm 3.86$ & $93.00 \pm 3.86$ & $96.67 \pm 3.86$ & $95.00 \pm 3.86$ \\
\hline$+240 \mathrm{~min}$ & $96.67 \pm 3.86$ & $86.67 \pm 3.86$ & $98.67 \pm 3.86$ & $85.33 \pm 3.86$ & $97.33 \pm 3.86$ \\
\hline
\end{tabular}

Note: Different letters on the same line indicate $p<0.05$ by Tukey's test; Fru- 25 = fructose $25 \mathrm{~g}$; Fru-50 = fructose $50 \mathrm{~g} ; \mathrm{Glu}-25=\mathrm{glucose} 25 \mathrm{~g} ; \mathrm{Glu}-50$ = glucose $50 \mathrm{~g}$.

Table 4 - Insulin levels and variations thereof between treatments at different blood sampling times

\begin{tabular}{lccccc}
\hline Period & \multicolumn{5}{c}{ Insulin $(\mu \mathrm{Ul} / \mathbf{m L})$} \\
\cline { 2 - 6 } & Corn & Glu-50 & Glu-25 & Fru-50 & Fru-25 \\
\hline Pretest & $3.42 \pm 2.70$ & $4.63 \pm 2.70$ & $2.51 \pm 2.70$ & $3.93 \pm 2.70$ & $4.77 \pm 2.70$ \\
$+30 \mathrm{~min}$ & $7.85 \pm 2.70^{\mathrm{ab}}$ & $12.27 \pm 2.70^{\mathrm{ab}}$ & $3.51 \pm 2.70^{\mathrm{b}}$ & $14.54 \pm 2.70^{\mathrm{a}}$ & $12.46 \pm 2.70^{\mathrm{ab}}$ \\
$+60 \mathrm{~min}$ & $4.93 \pm 2.70^{\mathrm{b}}$ & $17.12 \pm 2.70^{\mathrm{a}}$ & $3.17 \pm 2.70^{\mathrm{b}}$ & $11.87 \pm 2.70^{\mathrm{ab}}$ & $9.34 \pm 2.70^{\mathrm{ab}}$ \\
$+90 \mathrm{~min}$ & $4.85 \pm 2.70$ & $8.12 \pm 2.70$ & $4.35 \pm 2.70$ & $8.07 \pm 2.70$ & $5.40 \pm 2.70$ \\
$+120 \mathrm{~min}$ & $4.48 \pm 2.70$ & $6.46 \pm 2.70$ & $3.23 \pm 2.70$ & $5.07 \pm 2.70$ & $4.15 \pm 2.70$ \\
$+180 \mathrm{~min}$ & $4.84 \pm 2.70$ & $5.37 \pm 2.70$ & $2.45 \pm 2.70$ & $3.20 \pm 2.70$ & $3.27 \pm 2.70$ \\
\hline$+240 \mathrm{~min}$ & $3.45 \pm 2.70$ & $4.95 \pm 2.70$ & $2.36 \pm 2.70$ & $4.29 \pm 2.70$ & $3.11 \pm 2.70$ \\
\hline
\end{tabular}

Note: Different letters on the same line indicate $p<0.05$ by Tukey's test; Fru- $25=$ fructose $25 \mathrm{~g}$; Fru- 50 = fructose $50 \mathrm{~g} ; \mathrm{Glu}-25=\mathrm{glucose} 25 \mathrm{~g} ; \mathrm{Glu}-50=$ glucose $50 \mathrm{~g}$.

\section{Discussion}

The results of this research demonstrated that the glucose levels produced by the Glu-50 treatment were 20 to $30 \%$ higher than those produced by Fru-50 at 30 and 60 min after the infusion with energy-boosting supplements. This was expected, given that fructose is rapidly metabolized by the liver, while glucose continues circulating in the bloodstream. In contrast, insulin levels in the two groups were similar and were $30 \%$ higher in the Glu-50 treatment at 60 min than in in Fru-50. The lowest insulin levels were observed in Glu-25 at 30 and 60 min after infusion. Another finding was that both Glu-50 and Fru-50 treatments lowered the AST and ALT levels, indicating that increasing the calorie intake improves liver function without changing phosphorus levels in horses after overnight fasting.

\section{Variations in blood glucose and insulin levels}

Fructose and glucose infusions produce different changes in blood glucose levels because they are metabolized differently by the liver. Divergent effects of oral glucose or fructose supplementation on horses have been reported, thus prompting further studies about the use of these carbohydrates. 
Supplementation with pelleted glucose-rich concentrates significantly increased blood glucose and insulin levels in horses when compared with fructose (Vervuert et al., 2004). These authors found that during the use of these carbohydrates for resting horses, fructose supplementation is not advantageous. Conversely, Bullimore et al. (2000) did not report significant differences in blood glucose and insulin levels resulting from oral glucose and fructose supplementation. However, the latter researchers administered these carbohydrates directly in the stomach using a gastric tube, which did not simulate regular food ingestion. Thus, it should be noted that when horses ingest their food/pellets, sensors in the mouth and stomach are stimulated, activating different metabolic pathways associated with glucose/fructose absorption and insulin release (Dühlmeier et al., 2001). It is important to ensure that oral supplementation replicates the animals' natural behavior to ensure more accurate results. Therefore, blood infusion may produce more accurate data than those obtained via oral supplementation.

High fructose supplementation also interferes in blood $\mathrm{pH}$ in different groups of animals. Pyruvate and lactate are produced and released by the liver during fructose metabolism. Lactate is more energy efficient in glucose conversion and lipid synthesis (Egli et al., 2016), helping maintain calorie levels in different conditions. Moreover, increased blood lactate levels after fructose infusion may be associated with changes in blood $\mathrm{pH}$. These changes may be caused by external factors such as large amounts of energy boosters given to sick animals. In newborns, infusion with glucose and fructose at $1 \mathrm{~g} /$ $\mathrm{kg} / \mathrm{h}$ did not produce a significant change in blood $\mathrm{pH}$, but when the dose was raised to $2 \mathrm{~g} / \mathrm{Kg} / \mathrm{h}$, the blood pH decreased (Kaye et al., 1958). However, other authors consider that a dose exceeding $0.5-1.0 \mathrm{~g} / \mathrm{Kg}$ produces some degree of toxicity, manifested through hyperuricemia and lactic acidosis (Steinmann et al., 2016). The doses used in our research were lower $(0.13$ and $0.07 \mathrm{~g} / \mathrm{Kg})$ than those cited above, and healthy horses should be able to transform lactate into glucose efficiently. In very sick animals whose blood pH levels may be altered, it is important to measure lactate levels and other regulators of blood $\mathrm{pH}$ before and during fructose supplementation, if the fructose dose is higher than the doses used in this study.

In contrast, high dose fructose supplementation is associated with increased triglyceride levels and fatty liver, as well as insulin resistance and increased AST and ALT levels (Botezelli et al., 2010). This process is not clear in horses, but high dose supplementation may be important for animals in stress conditions, such as hospitalization or undergoing intensive training exercises. Such animals may be receiving high doses of fructose during long periods of time and/or frequent doses, in which case their health status should be reassessed at regular intervals. During parenteral nutrition, the estimated fructose dose should be around 0.3 $\mathrm{g} / \mathrm{Kg} / \mathrm{h}$. In this process, $50-70 \%$ of the fructose is converted to glucose, $20-25 \%$ to lactate plus pyruvate, $8 \%$ to glycogen, and $1-3 \%$ to triglycerides (Steinmann et al., 2016). This parenteral dose is higher than the doses applied to the horses 0.13 - $0.07 \mathrm{~g} / \mathrm{Kg}$ ) in this study, so no adverse effects were expected. Nevertheless, additional studies are needed to gain a better understanding of how this process affects horses.

New research has opened up other areas that associate fructose supplementation (oral or infusion) with appetite regulation. In sick animals, fructose metabolism has proved to be less affected by reduction of the general metabolism than glucose (Gonzalez et al., 2017), and the use of fructose is important for animals in stressful conditions, such as the postoperative period. Moreover, fructose is reportedly more active than glucose in some regions of the brain correlated with appetite and food intake (Luo et al., 2015), and fructose ingestion or infusion may contribute more toward continuous food intake, which is important during a patient's recovery. On the whole, these new forms of fructose supplementation may be important in equine medicine, not only for recovery of the general metabolism in different tissues but also for rapid restoration of appetite.

\section{Liver transaminase}

Liver transaminase, aspartate aminotransferase (AST) and alanine aminotransferase (ALT) are important biomarkers of the liver metabolism 
and are used to predict different diseases in this organ. Causes of metabolic syndrome are elevation of triglyceride levels, followed by increased concentrations of transaminase (Botezelli et al., 2010) produced by fatty liver. The mares used in this study were not obese and their body condition score was about 4.5. The Glu-50 and Fru-50 infusions lowered the AST levels, but the ALT levels were only reduced by the Fru-50 treatment. In horses with normal AST and ALT levels, a fructose (50 g/animal) or glucose (50 g/animal) infusion into the bloodstream after overnight fasting was apparently beneficial because it helped reduce the levels of these enzymes. However, such reductions need to be better evaluated, especially in animals receiving high dose fructose supplementation, because high doses of fructose are associated with fatty liver and metabolic syndrome in other animal species (Botezelli et al., 2010).

\section{Blood phosphorus and total protein levels}

Various authors have found that fructose is metabolized and phosphorylated by the liver faster than glucose, and this process generates more lactate and pyruvate (Gonzalez et al., 2017). This intense phosphorylation contributes to rapidly decrease blood phosphorus levels after fructose infusion. As mentioned earlier herein, we did not measure lactate levels in this study, but the absence of changes in blood phosphorus levels in the five experimental groups reinforces the idea that intermediate metabolites were well handled by these healthy horses when they were infused with fructose doses of 0.13 and $0.07 \mathrm{~g} / \mathrm{Kg}$.

In this study, the five groups showed no differences in blood phosphorus levels, which remained at characteristic values for healthy adult horses. Conversely, rapidly decreasing phosphorus levels, i.e., in less than $30 \mathrm{~min}$, have been observed in healthy humans or in humans with liver diseases, after fructose infusion when compared with glucose (Smith et al., 2016). However, 30 min after fructose and glucose infusion, blood phosphorus levels returned to normal in healthy humans (Steinmann et al., 2016). In our study, the first blood samples were collected $+30 \mathrm{~min}$ after infusion, and our methodology apparently did not contribute to detect possible differences between groups.

Lastly, no significant variations in TPP levels were observed in the experimental horses. Changes in TPP levels are associated with changes in plasma volume, and since all the animals in this study had unrestricted access to water throughout the experimental period and the volume of infused solution was small, i.e., less than one liter, the TPP volume remained unchanged.

\section{Conclusion}

In conclusion, this research demonstrated that glucose or fructose infused into the bloodstream of healthy horses produced different glycemic and insulin curves when equivalent doses of commercial energy-boosting supplements were used. A $50 \mathrm{~g}$ dose of these carbohydrates also brought about significant decreases in AST and ALT levels, but did not alter total plasma protein and phosphorus levels.

\section{References}

Borer KE, Bailey SR, Menzies-Gow NJ, Harris PA, Elliott $\mathrm{J}$. Effect of feeding glucose, fructose, and inulin on blood glucose and insulin concentrations in normal ponies and those predisposed to laminitis. J Anim Sci. 2012;90(9):3003-11.

Botezelli JD, Mora RF, Dalia RA, Moura LP, Cambri LT, Ghezzi AC, et al. Exercise counteracts fatty liver disease in rats fed on fructose-rich diet. Lipids Health Dis. 2010; 9:116.

Bullimore SR, Pagan JD, Harris PA, Hoekstra KE, Roose KA, Gardner SC, et al. Carbohydrate supplementation of horses during endurance exercise: comparison of fructose and glucose. J Nutr. 2000;130(7):1760-5.

Dühlmeier R, Deegen E, Fuhrmann H, Widdel A, Sallmann HP. Glucose-dependent insulinotropic polypeptide (GIP) and the enteroinsular axis in equines (Equus caballus). Comp Biochem Physiol A Mol Integr Physiol. 2001;129(2-3):563-75. 
Egli L, Lecoultre V, Cros J, Rosset R, Marques AS, Schneiter $\mathrm{P}$, et al. Exercise performed immediately after fructose ingestion enhances fructose oxidation and suppresses fructose storage. Am J Clin Nutr. 2016;103(2):348-55.

Elliott SS, Keim NL, Stern JS, Teff K, Havel PJ. Fructose, weight gain, and the insulin resistance syndrome. Am J Clin Nutr. 2002;76(5):911-22.

Geidl-Flueck B, Gerber PA. Insights into the hexose liver metabolism - glucose versus fructose. Nutrients. 2017;9(9):1026.

Gonzalez JT, Fuchs CJ, Betts JA, van Loon LJ. Glucose plus fructose ingestion for post-exercise recovery - greater than the sum of its parts? Nutrients. 2017;9(4):344.

Kaye R, Williams ML, Barbero G. Comparative study of glucose and fructose metabolism in infants with reference to utilization and to the accumulation of glycolytic intermediates. J Clin Invest. 1958;37(5):752-62.

Luo S, Monterosso JR, Sarpelleh K, Page KA. Differential effects of fructose versus glucose on brain and appetitive responses to food cues and decisions for food rewards. Proc Natl Acad Sci U S A. 2015;112(20):6509-14.

Mellor DJ. Operational details of the five domains model and its key applications to the assessment and management of animal welfare. Animals (Basel). 2017;7(8):60.
Nilsson LH, Hultman E. Liver and muscle glycogen in man after glucose and fructose infusion. Scand J Clin Lab Invest. 1974;33(1):5-10.

Pribylová H, Kimlová I, Stroufová A. The effect of intravenous fructose and glucose on metabolism and plasma insulin levels in newborn infants. Biol Neonate. 1973; 23(3): 205-13.

Smith S, Harris PA, Menzies-Gow NJ. Comparison of the in-feed glucose tolerance test and the oral sugar test. Equine Vet J. 2016;48(2):224-7.

Steinmann B, Gitzelmann R, Van den Berghe G. Disorders of Fructose Metabolism. In: Valle D (E.). The Online Metabolic and Molecular Bases of Inherited Disease. The McGraw-Hill Companies Inc; 2016 [acesso 20 out 2018]. Disponível em: https://tinyurl.com/yczejkgo.

Vervuert I, Coenen M, Bichmann M. Comparison of the effects of fructose and glucose supplementation on metabolic responses in resting and exercising horses. J Vet Med A Physiol Pathol Clin Med. 2004;51(4):171-7. 